\title{
Grundtvig og Kierkegaard som grundlæggere af en moderne social bevidsthed
}

\section{afChrista Kühnhold}

Følgende overvejelser holder sig snævert til det emne, overskriften angiver, nemlig spørgsmålet: hvorledes har Grundtvig og Kierkegaard været i stand til at udvikle en ny social bevidsthed, hvis gyldighed står ved magt den dag i dag? Af tidsmæssige grunde har det været nødvendigt bevidst at give afkald på at påvise direkte forbindelser hos de to tænkere til det "moderne gennembrud ", skønt de foreligger i stort tal.

På trods af en endnu almindeligt fastholdt a-historisk tendens inden for moderne videnskab, der, blot den ser 200 år tilbage $i$ tiden, anser sig for at være litteratur-historisk, vil jeg her, som ofte før, hævde, at vi ikke bliver i stand til at forstå vores nutid, dersom vi ikke lærer at tænke vores fortids tanker, også de tanker, der tænktes for over 200 år siden. Den senere fortid, f.eks. "det moderne gennembrud «, kan vi ikke lære at erkende og forstå, vi har ingen anelse om, hvorledes den er struktureret, uden nøje at kende de tanker, der forberedte og formede det, de tanker, der udgjorde det materiale, hvoraf det blev til.

Et gennembrud kommer ikke pludseligt og tilfældigt; det har længe været under forberedelse. Et gennembrud forudsætter lang tids bestandige stormløb mod bolværker, før endelig digerne gennembrydes. Hvorfra kom da disse banebrydende idéer? og hvem beredte dem deres vej? Ser vi på hovedpunkterne hos de banebrydende tænkere, må vi fremdeles spørge: hvorledes var deres oprindelige anlæg, og hvorledes udviklede de sig?

1. De to mest indflydelsesrige kritikere i Danmark af deres samtid, ja af hele det 19. århundrede, var N. F. S. Grundtvig og Søren Kierkegaard; virkningen af deres indsats gør sig gældende den 
dag i dag og kan ikke overvurderes. Hvorledes virkede da disse to stridsmænd, der livet igennem ikke bestilte andet end med hele deres eksistens på spil at kæmpe mod et forstokket sprog, en forstokket kirke, en forstokket stat, og mod de mennesker, der gemte sig bag forstokketheden, og deres ideologi?

Man mister pusten, når man gør sig det klart, hvad der sker i Danmark i det 19. århundredes første halvdel. Først det kald til et nyt kulturprogram, der udgik fra Grundtvig: frihed for mennesket, også kvindernes frihed, frihed fra kirkens bånd, frihed for religionen, frihed for videnskaben, for pædagogikken, frihed $\mathrm{i}$ politisk, økonomisk og demokratisk betydning, "Frihed til at være sin Troe bekiendt, naar man har nogen, og sin Vantroe med, naar man ingen Troe har, Frihed til at bruge Haand og Fod, som man vil, lige Adgang til Stilling og Syssel, naar man paa hvilkensomhelst Maade viser, at man duer til den, og alt Saadant, som man veed altid er til fælles Bedste. " (Danskeren, august 1848, s. 373 ff.).

"Frihed for Alt, hvad der stammer fra Aand, Som ikke ændres, men arges ved Baand, Virker skinbundet det Værste i Løn, Tæmmes alene ved Thor-Karmens Døn« (Nordens Mytologi, 1832)

Her siger Grundtvig rent ud: om noget skader og ødelægger mennesket, da er det ufrihed. Kun torden og lynild, dvs. kamp, kan befri for tvang.

Grundtvigs ven, Høgsbro, formulerede kort Grundtvigs krav således: det gælder om "at skaffe den jævne mand, dvs. bonden, indsigt $\mathrm{i}$, hvad der tjener helheden til gavn. "Det tjener helheden til gavn at oplyse om ufrihed, afhængighed og umyndighed. Grundtvigs udkast til en folkehøjskole, førte efter 1864, uforstyrret af den følgende tids forfatningskampe, til den danske nations frelsende åndelige grundlæggelse.

Sammensluttet i partiet "Venstre" gennemførte bønder under 80 'ernes krise en økonomisk og social revolution, idet landbruget omstilledes til intensiv dyrkning og forædling af mejeri- og slagteriprodukter, tilmed i landbrugets egne andelsvirksomheder. Kulturelt var landbobefolkningens rejsning allerede begyndt med folkehøjskolernes videreuddannelse. 
Spørger vi, hvorfor historien, landets nordgermansk-danske fortid, var blevet så vigtig for Grundtvig, støder vi på det allerede nævnte nyskabende begreb: friheden. Friheden er hans tænknings centrum. I Grundtvigs ungdom var bønderne endnu ufrie. I hans modnere år afgav enevælden, der endnu sad fast i saddelen, kun sparsomt enkelte rettigheder til bondestanden. Med sine centrale begreber "Ord " og "Maal" pegede Grundtvig nu på alle menneskers skabende fællesskab: dette fællesskab ville han se virkeliggjort i det statsligt organiserede folks måde at handle på.

Grundlaget for en sådan handlemăde fandt han givet $\mathrm{i}$ den vækst af det fælles sprog, som betinges af menneskers samvirke. I en af sine rigsdagstaler pegede han på nødvendigheden af "at give hele Folkeungdommen uden Hensyn til Stand og Syssel Adgang til at faae en bedre Grund i Modersmaalet og en bedre Oplysning om Fædrelandet og Alt, hvad dansk er, end der hidtil har været nogen offentlig Mulighed til her i Landet at erhverve, til at tiene det fælles Bedste til Folkets Gavn. "Her imødegik han Madvigs manglende forståelse. Madvig havde udtalt, at "Regieringen ikke vil vide af en særskilt Characteeren af Danskhed monopoliserende Undervisningsanstalt. " Dette var en klar fornægtelse af Grundtvigs planer, der omfattede "Fædrelandets, altså gamle Danmarks Sprog, Historie, Statistik og Statsforfatning, de for Borgeren i private Stillinger vigtigste Dele af Lovgivningen, og de administrative og communale Forhold. " (Forordet til Lykønskning til Danmark, s. 3). Hvad Grundtvig tilstræbte, var altså en "Samfundsskole «; kongen selv havde stået på hans side i denne sag.

En opdeling af samfundet, der hvilede på politisk og økonomisk afhængighed, havde restriktivt virkende fortrængt Danmarks sproglige egen-tilværelse til landsbyfællesskaberne på landet. Grundtvig og hans folkehøjskoler knyttede til ved den nordiske oldtids og middelalders kilder og gav således nye kræfter til det af kirke, videnskab og økonomi udtørrede sprog og dermed til dansk åndsliv, frem for alt til de laveste befolkningslags politiske bevidsthed. "Det er i sin Orden, at jeg er udraabt for halvgal og betragtes af den latinske Minister som en Taabe, fordi jeg vil have fælles dansk Oplysning og Dannelse i Landet, der skal agtes langt høiere end den Oplysning og Dannelse i en enkelt Retning, som Enkeltmanden kan have Lyst.og Anlæg til; thi for Latinerne gives der kun to dannede Folkefærd, som begge ere døde for læn- 
ge siden, nemlig Grækere og Romere. Alle andre Folkefærd ere for dem som for Romerne Barbarer " (Danskeren, 20. december 1848 , s. 636 f.).

Man burde faktisk i virkeligheden tale om en BernstorffGrundtvigsk reform, der i Danmark forhindrede de kulturrevolutionære situationer, som måtte komme $\mathrm{i}$ andre lande med undertrykte nationalsprog, f.eks. hos baskere og bretoner.

Hvorledes skulle man kunne tro, at Grundtvig ikke måtte anse det for den mest selvfølgelige sag af verden at begive sig til rigsdagen og dér højlydt at fremsætte sine krav og gøre det årtier igennem? Han måtte blive politiker, og han blev det. Han var et af de første medlemmer af den grundlovgivende rigsforsamling og blev, mægtig i ord, en ubønhørlig stridsmand i parlamentet. Som vi senere skal se, gjaldt det for Grundtvig om at omsætte billedet af den germanske ting-bonde, der åben, fri og selvbevidst kunne sige sin mening, til sin egen tid. "Ethvert Menneske", et udtryk, som Kierkegaard bruger hundreder af gange, skulle være i stand til selvbevidst at hævde sit anliggende, sin ret (oldnordisk: ping).

Derfor var det, stadig ifølge Grundtvig, nødvendigt at give det allerlaveste sociale lag værktøj i hænde til sin egen befrielse, nemlig oplysning og viden. Det selvbevidste menneske i frihed, det er Grundtvigs mål, hvad man også hører i følgende principielle sætning: "Altid at unde Næsten samme Frihed, som man selv gjør Krav paa." Af personlig kristen overbevisning var han rede til at samarbejde med enhver politisk og ideologisk modstander. "Det er den høiere Christelige Anskuelse..., der har givet den nye Folke-Verdens Tanke-Gang, Dannelse og Vidskab det universalmenneskelige Præg, som den gamle Verden fattedes, " og det er derfor "den eneste ægte Grund-Anskuelse af Menneske-Livet. « Den grundanskuelse beror på den udelukkende kristne tanke, at alle mennesker er lige over for Gud; mennesket er jo født til fuldkommenhed, skabt i Guds billede. Her finder Grundtvig grundlaget for den til dato ikke overvundne utopi, drømmen om fremtidens menneske. Han kæmper for det frie selvbevidste menneske, der fri over for enhver form for tvang også er fri over for den misundelse, det nag og den magtsyge, der lover ham herredømme over andre mennesker. Et menneske, der selv er fri for tvang, behøver heller ikke at udøve magt over for andre. Blot et blik på 
den nyeste dybdepsykologiske forskning - der dog ikke forekommer os ret ny i forhold til vores historiske verden - bekræfter denne erkendelse hos Grundtvig. Denne oprindeligt kristelige og bestemt ikke "kirkelige" anskuelse hos Grundtvig vedrører menneskelivet og tilsiges os af "både Historien og den daglige Erfaring " (VU II, 25-27).

I modsætning til Kierkegaard var Grundtvig praktisk og politisk indstillet, og allerede som ganske ung mand noterede han $i$ sin dagbog 1802: "den vakte nyt Mod hos mig til engang i Tiden ogsaa at opbyde Alt for Bønders Opklaring (dvs. oplysning) og... Harme og Uvilje mod alle Bondeplagere, der existerer, og især mod dem, der omringer mig, hvoraf kun faa have Religiøsitet - og da er den falsk - men ingen Moralitet."

Grundtvigs hele indsats, ja fra hans allerførste tænkning som skoledreng, gik ud på at øve en åben, energisk kritik over for alt, hvad der var uægte, forvansket, uden overensstemmelse med sandheden, og således en kritik af hans samtid.

Hans liv var en eneste protest mod tidsalderens herskende tænkesæt, hvad vi bl.a. kan se af hans holdning, afvigende fra alle de forestillinger, der omgav ham, over for kvinderne; en tid lang havde han således Mathilde Fibiger boende i sit hus.

Det eneste middel til at tæmme det afskyvækkende fordærv, han fandt i sin samtid, og som afspejlede sig i undertrykkelse, hovmod, falskhed og profitmageri, fandt han imidlertid i tidens befrielse fra tvang. Dette kan ikke betones ofte nok. Således indledte han en fri, videnskabelig, politisk og pædagogisk diskussion.

Det var også ham, der altid anerkendte sin modstander som menneske, hvad han klart bringer til udtryk i digtet "Menneske først og Christen saa, kun det er Livets Orden. " Enhver må vel kunne indse, at anerkendelsen af denne hans menneskelige holdning har gjort det muligt at tolerere mange senere slags frihed af politisk, agitatorisk eller anden art.

"Frihed lad være vort Løsen i Nord, Frihed for Loke saavel som for Thor."

I digtet "Kirken og Skolen« er Grundtvigs sociale program klart defineret. Lad mig her citere de betegnende verslinjer: 
1) "Ordet frit i hver en Mund, (str. 9)

som den tør forsvare."

2) "Øret frit paa samme Grund

Vende sig fra Mund til Mund,

Hvor det bedst kan høre!«

3) "Bogen fri i hver Mands Haand, (str. 10)

som den vil oplade. "

4) "Livet frit for Kirke-Tugt, (str. 11)

Som er ei i Ordet."

5) "Derfor bort med alle Baand. « (str. 7)

Her kunne man spørge: hvorledes ville man vel, næsten 40 år senere have reageret på nye aggressive og til dels hadske proklamationer, om ikke Grundtvig allerede i 1836 havde kæmpet for pressefrihed, meningsfrihed og frihed for kirkens tvang, med hele sin eksistens på spil, uafladeligt, bevidst, risikovillig, uden at vige tilbage for nogen foragt, der dog i rigeligt mål blev ham til del fra alle sider. Begrebet "det levende ord" står hos Grundtvig bestandig i centrum som hans tankegangs brændglas.

Kun folkesprogene, der omfatter alle folkets sociale lag, gælder for Grundtvig som levende ord. Folkesprogene giver næring til alle befolkningslagenes åndelige liv og næres selv af dem. Denne gensidighed i sprogbevægelsen, åndslivets uendelig mange udtryksformer, der knytter sig til enhver sproglig ytring, virker på længere sigt som aftryk i sprogbrugen. Sproget er et alment-socialt fænomen. Dvs. den menneskelige tale præges strukturelt af den historisk-traditive tilværelses elementer og af den situative oplevelseskarakter. At dette er sprogets væsen, betegnes på dansk og dermed også af Grundtvig med ordet "Maal" og med henblik på den enkelte talendes rodfæestethed i den familie, hvori han er vokset op, med ordet "Modersmaal".

Vi kommer ikke uden om en nærmere overvejelse af udtrykkene "Ord " og "Maal « i Grundtvigs tænkning. Begge udtryk er centrale begreber hos ham, og begge indtager en afgørende funktion $i$ hans forestilling om "Samfund " og om den af tvang befriede enkeltpersons forhold til samfundets fællesskab.

Ordet "Maal " udtrykker en vigtig nuance af det mere omfattende 
begreb "sprog ". "Sprog " er lærebøgernes og ordbøgernes sprog, også sproget i ordbøger over de såkaldt "døde " sprog. Ordet "Maal " derimod betyder stemme, tale, (det talte) sprog, altså i første række det, som ethvert skrift lader ude af betragtning; i betydningen "tale" viser det hen til den levende samtale og først i ordets tredje betydning til sprogets mere eller mindre stivnede former, f.eks. i dialekter eller standsbestemte sprogformer.

At ordet "Maal" således viser hen til det taltes helhed under sprogbrugen, er en kendsgerning, der er dybt forankret i dette ords historie. Over formen " mahla " går det tilbage til ældre germansk " mapla" og hører sammen med gotisk " mapl ", forsamlingsplads, "mapljan", at tale, og oht. "mahal", retsforsamling. Betydningen "tale", "det talte sprog", går altså tilbage til optræden for retten. Retten er det sted, hvor den frie mand frit kunne fremstille sin sag, og hvor forsamlingen, samfundet, udvekslede og meddelte meninger og standpunkter. Her samles alle befolkningslag, her konstitueres samværet ved tale, her foregår der kommunikation. Har man forstået, hvad ordet "Maal " betyder, forstår man også, hvad der konstituerede det, som Grundtvig kaldte "vore Fædres Sprog".

På tingets konstitutive folkeforsamling beskyttes og bevares den enkeltes, den frie selvbevidste bondes, interesse; ved sin juridiske og kultiske tale skaber folkeforsamlingen stammens enhed. Her bliver det klart, hvorledes to fundamentale drivkræfter for menneskeligt åndsliv, fædrenes ærværdige tradition og tingsforhandlingens væddestrid, samvirker for at præge en levende enhed af gammelt og nyt som varige forbilleder.

Grundtvig, der havde nøje kendskab til disse historiske sammenhænge, siger: "Det er kun gjennem Folkenes Modersmaal, at Menneske-Ordet er i levende Virksomhed. " (Den christelige Børnelærdom, VU VI 108 f.) - "og at ethvert Tungemaals levende Udvikling i aandelig Retning kun gaaer for sig under en tilsvarende Udvikling af Folkelivet i det Hele."

Betydningen af "Maal", "Ord" og "Frihed" for det enkelte menneske følger af Grundtvigs egne, her anførte, formuleringer. Det, som binder det frie enkelte menneske og fællesskabet sammen, er "Ordet", "Maalet".

Den afgørende betydning for social frihed og enhed, som 
Grundtvig tillagde det talte ord, havde sin grund deri, at det ifølge sin natur skaber bindinger mellem mennesker og giver kræfter, dvs. fremmer livet. Denne indsigt havde Grundtvig tilegnet sig under sine omfattende og grundige filologiske studier, og den gav han videre til sin samtid. Med sin tænknings centrale vægt står han her banebrydende på folkets, de ufries, side, i utrættelig kamp for deres værdighed og frihed.

Grundtvig og Kierkegaard er de første, der anvender ord og vendinger fra den jævne mands sprog i teoretiske afhandlinger, og som også skriver dansk, som man taler det.

Men hensyn til det "hvem" og det "hvorledes ", der ligger gemt bag tingenes og begivenhedernes "hvad ", ville Grundtvig - ligesom Kierkegaard - overføre den inhumane ligegyldighed, der prægede det sprog, der vilkårligt valgt anvendtes inden for samfund, forvaltning og videnskab, til et sprog, der forholdt sig til hvert enkelt menneske og var den kraft, der skabte enhver virkelighed. (Om Videnskabeligheds Forhold til Erfaring og sund Menneske-Forstand, DV II 37ff., 1817). For menneskelivets skyld, for vores virkelige menneskeligheds skyld, der ikke som hidtil « - og lige til den dag i dag, kan vi roligt tilføje - "misbruger medmennesket som informationskilde og profitfremmende middel til eget formål, men tværtimod søger at styrke ham $i$ hans personlighed, behøver vi et sprog, der svarer til denne nye, sandt menneskelige måde at handle på, nemlig det erfarings- og historiemættede modersmål. For ethvert menneskes selvstændigheds og værdigheds skyld bør modersmålet også gøres tilgængeligt for hver eneste én. Af denne nødvendighed udspringer tanken om folkehøjskolen.

Grundtvigs kamp mod videnskabens "pluddervælske" abstraktion skabes ene og alene af hans bekymring for de mennesker, han er vokset op iblandt, bønderkarlene, der ingen lejlighed havde til abstrakt at lade deres forstand afrette i latinskoler og derfor var udelukkede fra alt, også udelukkede fra deres kreds, der dirigerede, manipulerede og udbyttede dem.

Derfor begyndte Grundtvig sin kamp mod idealismen og dens abstraktion fra det enkelte menneske, idet han vendte sig mod Schelling, ligesom Kierkegaard i sin kamp vendte sig mod Hegel. Det galder om at udfolde folkesprogets "levende virksomhed ", således at den når hver eneste én og positivt styrker ham. Derfor 
er det nødvendigt at øse af menneskeslægtens erfaring, af historien og dermed også af sproghistorien. Det gælder om klart at vise sammenhængen mellem menneskeslægtens og det enkelte menneskes erfaring. (Om Videnskabeligheds Forhold til Erfaring og sund Menneskeforstand, DV II). Derfor retter Grundtvig, ligesom senere Kierkegaard, sine skarpeste våben mod videnskabens indholdstomme pseudosprog, der for dem begge var repræsenteret $\mathrm{i}$ den idealistiske filosofis sprog og dennes overmodige påstand om at fremstille det menneskelige alment og fuldgyldigt. De kæmper mod deres samtids filosofi fordi de erkender dens tilintetgørende ligegyldighed over for det enkelte menneske, "den menige mand", - en ligegyldighed, der forstærkes ved almén etisk normerings "chimæriske» begrebslighed.

Hvad Grundtvig ønsker, er "det Nærværende, som det virkelig er" (Den danske Statskirke upartisk betragtet, 1834 VU III, s. 321). Grundtvig så det enkelste menneskes opfyldte livsvirkelighed truet af "fantomet, tænkningens abstraktion", af "objektivitetens falsum ", fordi en sådan tænkning bestrider den enkeltes ret til den selvstændige bevægelse, der alene avler virkelighed. Frygten for, hvor let mennesket lader sig manipulere ved vilkårlige systemskitser $\mathrm{i}$ et sprog, der bevidst holdes uforståeligt, driver Grundtvig til med stor polemisk skarphed at kæmpe mod videnskabens "kragemål", der ifølge ham benyttes af professorer og docenter, politikere og statens tjenere med det formål at "umyndiggøre " folket, "slå det åndeligt ihjel ".

Den eneste sandt sociale holdning består $i$ anerkendelsen af hvert enkelt menneske. Men kun ved "det levende ord " i dets afhængighed af det absolut gode bliver det enkelte menneske i stand til at leve i fællesskabet og for fællesskabet.

2. Som den kapitalistsøn og storstadens levemand, Kierkegaard var, havde han, modsat Grundtvig, i hvert fald i sin ungdom intet umiddelbart forhold til andre samfundslag. Han nåede frem til sin menneskeopfattelse ved en fænomenologisk iagttagelse af sig selv og sin omverden. Han måtte gå en anden vej end Grundtvig; hans vej var betinget af hans opdragelse og af hans psykes afgørende prægning af barndomshjemmets abnorme betingelser og konstellationer. På denne baggrund måtte han finde sin vej til social forståelse og til den enhedsopfattelse af folk og individ, der er forud- 
sætningen for et harmonisk fællesskab. For ham fandtes der ingen umiddelbare naturlige indtryk som for Grundtvig, kun abstraktioner fra det menneskelige, som han måtte overvinde under møje og besvær.

På ganske anden måde end Grundtvig tilkæmpede han sig således sin vej. Men målet var det samme: friheden for det enkelte menneske, der er sig selv og sin egen beredthed til at hengive sig for "sagen" bevidst, en sag, der altid kun kan være fællesskabets sag.

Lad mig her i korte træk skitsere trinene i det intentionale bevægelsesforløb, hvorved den enkelte gør sig selv til et "organisk led " $i$ et "organisk hele", som Kierkegaard siger, nemlig i sit fællesskab.

Det er den enkelte, der vover en indsats for en bestemt sag, for "det bestemte Noget", og således positivt bringer det godes sag i verden i bevægelse. I hengivelsen til det gode konstitueres den "berettigede virkelighed ". Arbejdet for "sagen " gælder altid også medmennesket, "den fattige, den syge, forbryderen". Kun den enkelte formår, i sin anerkendelse af ethvert medmenneskes givne selvstændighed, af alle kræfter at arbejde på "at bevare den andens givne selvstændighed og at styrke ham efter evne". Den enkelte, der vover at gå imod udnyttelse og undertrykkelse iværksat af et råddent sindelag, kun han alene er kilden til bevægelsen hen imod et nyt menneske: "Af naturen er ethvert menneske anlagt til at blive tænker" (F.u.Z. s. 69). "Jeg kræver af ethvert menneske, at han ikke skal tænke så umenneskeligt om sig selv, som om han ikke havde lov til at træde ind i hine paladser, i hvilke ikke blot mindet om de udvalgte dvæler, men hvor de selv langt mere er til stede" (F.u.Z. s. 69).

Den bitre kamp mod Hegels metafysik førte Kierkegaard til det punkt i Hegels system, der var dets ømme punkt, som han radikalt kunne gå til angreb imod. Dette punkt er begyndelsen til Hegels logik. Som Hegels sprog afslører det, sker der nemlig her bevægelse "af sig selv". Et ubestemt "det" sætter sig "af sig selv". Der er ikke tale om, hvorledes bevægelsen sker, eller om, hvem der forårsager den. Den sker abstrakt, uden at forholde sig til noget eller nogen, "af sig selv «! I et såkaldt »objektivt « systems rene tænkning sker der noget, som det enkelte menneske, fra hvem der abstraheres, kun kan møde som et under, og notere sig som et 
under. Ingen ved, hvorledes bevægelsen sker, ingen hvem der er dens bærer!

For Kierkegard er bevægelsen "af sig selv ", der er forårsaget af det ubestemte "det", et usandfærdigt hjernespind. For ham sker bevægelse kun i frihed. Og kun et menneske, nemlig det enkelte menneske, "ethvert menneske", kan, som han fremhæver det hundreder af gange, være denne friheds bærer.

Ved at stille spørgsmålet om, hvorledes denne bevægelse sker og hvem, der forårsager den, afslører Kierkegaard Hegels bedrag over for det menneskelige. Han påviser, at denne ominøse (skæbnesvangre) bevægelse "af sig selv" er hjernespind, et bedrag iværksat af en gruppe mennesker, der holder systemet op for sig som et beskyttende skjold, for, uden at kunne drages til ansvar som enkeltpersoner, bag det at kunne skjule deres sande handleog tænkemåde. Deres sande handlemåde viser sig at være udplyndring og undertrykkelse af de mindre kloge, de mindre smarte, som de stræber efter at manipulere og udnytte. Som funktionærer $i$ et system, der har den "absolutte ånds " beskyttende jernskjold at byde på, har de været rygraden både $\mathrm{i}$ det prøjsiske statsapparat og i nationalsocialismens apparat til tilintetgørelse og udryddelse af mennesker. Herskesyge og magtbegærlige systemer, som i historiens løb har vundet fodfæste inden for alle kristne kirker, danner ingen undtagelse.

For Kierkegaard var det mere end klart, at udplyndring, pågribelse og angreb var det faktiske indhold af begyndelsen til Hegels logik, og at der måtte sættes ind mod dette system og begyndelsen til det. Et system, der foregiver at kunne sætte bevægelse $\mathrm{i}$ gang på den enkeltes vegne, ja hævder altid at have gjort det, betyder den enkeltes umyndiggørelse og ødelægger og søndertramper "den selvstændighed, der er ethvert menneske givet. " Umyndiggørelsen udleverer ham til udplyndring, udnyttelse og manipulation.

Især vakte det Kierkegaards ophidselse at måtte erkende, at den magt, der i historiens løb var blevet udøvet over for det enkelte menneske, udgik fra kirken i statens klædebon. Staten forklædt som kirke og kirken forklædt som stat har århundrederne igennem i uophørlig gensidighed f.eks. fortrængt betydningen af ordet "lidelse" som betegnelse for en fri, selvstændig bevægelse, ved en sammenblanding med ordet "lede», der er af anden oprin- 
delse. Ordet "lede" betyder oprindeligt modgang, en udefra kommende vanskæbne. Men kirken afskaffede ordets positive betydning for at bilde kirkefolket ind, at bibelen krævede, at man skulle tåle underkastelse, tvang og udnyttelse. Også dette sproglige bedrag, hvori kirken er skyldig, har Kierkegaard afsløret og atter adskilt begreberne "lidelse" og "lede".

"Disse ulykkelige millioner, som man har snydt for deres penge (og for deres liv) og stadig snyder, som man brugte som middel (arbejdskraft) og franarrede det evige, idet man fortalte dem løgnehistorier " (XIV, 180) og videre: "Profitten er Sandhed i Kirkehistorien. "Løgnehistorier og eventyr fortaltes for folket for at gøre det muligt for kirkefyrsterne at holde deres fem maitresser, med hver en slotsfløj og fyrsteligt udstyr.

Dette skammelige bedrag mod mennesket, der i sin fremadskriden i historien vel modificeres, men ikke ændrer sig, fortsættes ifølge Kierkegaard i borgerskabets kapitalistiske adfærd. "For Penge-Fordelens og den sandselige Magts Skyld " spiller man den brave borger for at kunne udnytte, snyde og bedrage sit medmenneske, den fattige.

Et udtryk, der går igennem hele Kierkegaards litterære produktion, er "ethvert menneske", for som skribent kender han ikke til klasseforskelle, og således tiltaler han også den menige mand, den eneste, der ved, hvad det vil sige at være udsat for udplyndring og bedrageri:

"Thi ikkesandt, Du menige Mand, det kan Du meget godt forstaae, jeg mener, at just Du kan langt lettere og bedre forstaae det end fordærvet Fornemhed, ikkesandt, dette kan Du ypperligt forstaae" (XIV, 97).

Kierkegaards kritik af den samfundsmæssige overbygning, der kun er interesseret i egen fordel, i profitten, som han siger, fremgår særlig tydeligt af hans omfangsrige sprogkritik. Det er tjenestepigen og landsoldaten, der ikke alene ejer sprogets "indre oprindelighed «, men også kraften til at overvinde tankeløsheden og den såkaldte åndrighed, overbygningens udskillelse i samfundet. "Saasnart der derimod kommer et Menneske, som fører Primitivitet med sig, saa han altsaa ikke siger: man maa tage Verden som den er... så bliver Alt til Liv“ (XI 21 A 46).

Disse ord tager sigte på former for social tvang $\mathrm{i}$ hans samtids overklasse, der udelukkende måtte have interesse $\mathrm{i}$ at fastholde sin 
magt- og undertrykkelsesposition, og som for at holde sig oppe og kunne herske kun kendte til et eneste bud, tilpasningens. "Ondt som sproget er mennesket, unøjagtigt, usandfærdigt " (VII, 271), når det gælder om at udnytte og bedrage den åndeligt underlegne (XII, 48). "Jo mere jeg forfølger Sagen, jo mere seer jeg, at Forvirringen stikker ikke blot i Danmark, ikke blot i Protestantismen, og ikke blot i Christenheden, men at den stikker i Menneske-Naturen og dermed i det Tyve-Sprog, som (vi) Mennesker tale" (Pap. XI, 2 a 37).

Det nye sociale menneske skabes ved daglig selvovervindelse for den fælles sags skyld. Den spænding, som mennesket dagligt må nedbryde, giver mulighed for menneskelig vækst, grundlaget for ethvert harmonisk samfunds opretholdelse af livet.

Uden her blot at kunne antyde hele problemet i Kierkegaards kommunikationsteori, må man dog fremhæve dens fundamentale træks betydning for Kierkegaards moderne sociale forestillinger; Kierkegaards forståelse af, at et samvær uden vilje til at fremme medmenneskets vel og hjælpe det er usocialt og derfor umenneskeligt og meningsløst, fører ham til at udarbejde en fuldstændig ny kommunikationsteori. Kun som etisk ansvarlig, målrettet positivt virkende er kommunikationen levende. Det vigtigste er at fremme det andet menneskes egne kræfter. Objektiv vidensmeddelelse er ligegyldig. En vidensformidling, der direkte, som en computer afgiver død information, kan ikke betegnes som kommunikation. "Nu har vi tænkt Meddelelsens Dialektik igjennem som Viden og see, at den er afskaffet. Nu følger et nyt Begreb af Meddelelsen " (VIII, 2 B B1, 12).

"Egenkjærlighedens udryddelse overvinder Alt, hvad der stiller sig hindrende i Vejen for Frembringelsen af Frugt i Kommunikationen. Og det er en uhyre Anstrengelse at arbeide paa den Maade for Samfundets fælles Bedste."

3. Grundtvig og Kierkegaard har ganske vist ikke taget offentlig stilling på samme måde i dagens debat, men begge har beslutsomt arbejdet henimod forvandlingen af alle menneskers bevidsthedsstruktur som grundlag for en effektiv fornyelse og derved banet vej for vor tids statsborgerlige bevidsthed. Alle det "moderne gennembruds « kendte krav var allerede rejst af Grundtvig og Kierkegaard. Virkeliggørelsen af sociale reformer som dem, 
der har fundet sted i Nord- og Vesteuropa har kun været mulig, fordi disse mænd gjorde det enkelte ansvarlige menneskes problem til genstand for deres lidenskabelige arbejde, og det på en radikal måde, der bragte alle hidtidige forestillinger til fald. Deres indflydelse gjorde også borgerlige kræfter i stand til endelig at forstå sociale krav, tilslutte sig dem og således give mulighed for reformer.

Grundtvig og Kierkegaard skabte ved deres arbejde de fænomenologiske fundamenter til ethvert socialt verdensbillede. Således har både Grundtvig og Kierkegaard før Karl Marx og endnu længere før hans "sludrevorne" eftersnakkere i vor tid tænkt den tanke, at "ethvert Menneske" - et af de hyppigst forekommende begreber hos Kierkegaard - kan være skabende og også burde være det, blot det ikke meningsløst vender sig mod fællesskabet og mod sig selv; hos Kierkegaard finder vi denne tanke udtrykt i endegyldig klarhed.

Det burde også gå op for vor tids mennesker, at Kierkegaard såvel som Grundtvig har afsløret den moderne vesterlandske tænknings afhængighed af oprindelig kristen tænkning, og at denne afhængighed deles selv af den moderne kommunisme.

Grundtvig og Kierkegaard viede deres kræfter til at skabe fundamenterne til et nyt menneskesyn og en ny verdensopfattelse. De viede dem til spørgsmålet om, hvorledes mennesket skulle undgå den fare, hvormed en rationel-teknisk tænkning, løst fra alt medmenneskeligt, og en uforpligtet, metafysisk-idealistisk tænkning truer det. "Al Fordærvelse vil tilsidst komme fra $\mathrm{Na}$ turvidenskaben, " siger Kierkegaard (Pap. VII, 1 A 186, 123).

Roden til det, hvorom de er fælles, er kampen for den menneskelige selvbestemmelses fundamenter og betingelser. 